\title{
THE ECONOMIC COVERAGE OF THE FAIR LABOR STANDARDS ACT: A STATISTICAL STUDY
}

\author{
Carroll R. Daugherty*
}

The administrative reason for wanting to measure the coverage of the Fair Labor Standards Act and the extent of low wages and long hours in covered employment was the need for knowing in general terms how much work would have to be done in effectuating the Act, and where it would have to be done. The provisions of the Act affect employees who are engaged in (interstate) commerce or the production of goods for (interstate) commerce. Measurement of the Act's coverage is, therefore, an enumeration of employees so engaged. No systematic attempt has yet been made to provide a specific answer to this question, or to the corollary question of the number of local-selling enterprises and employees directly competing with those selling in interstate commerce. Such an enumeration, together with subsidiary information on the quantity of goods and services involved, would undoubtedly be useful. It might, for example, serve to persuade hitherto unconvinced legislators and judges of the importance of removing the economic blockages arising when an industry or an enterprise is required to operate in a legal framework that may be significantly different in each of the states in which it does business. It would be useful in an analysis of how trade practices or labor standards which have come to be regarded as undesirable can spread through the industrial system or reshape the location and conduct of industry, as may happen when a given region of the country makes a late start in industry, and tries to compensate for that handicap by paying unduly low wages.

It was impracticable to count the employees covered by the Act, not only because final decision on coverage rests with the courts under the terms of the Act, but also because of the staggering statistical difficulties to be overcome. A complete census could be taken as of a given month, but its cost would be prohibitive both in public expense and in cost to business. Furthermore, some employees may be within the definition of coverage one month and outside of it the next. Fortunately-and rather obviously-a census was not essential to the effective operation of the Division. The Administration needed answers to the questions on the number of employees covered by the Act and the number of employees immediately affected by the minimum wage and maximum hour provisions that took effect October 24, I938. The estimates reported briefly herein are not the results of exhaustive survey; they are rough ap-

*A.B., I92x, Lebanon Valley College; M.A., 1924, Ph.D., 1927, University of Pennsylvania. Chief Economist, Wage and Hour Division, United States Department of Labor. Professor of Economics (on leave), University of Pittsburgh. Author, Labor Problems in American Industry; co-author, Economics of the Iron and Steel Industry. 
proximations intended to meet an administrative need. A high degree of precision was not necessary and was not sought. They are based on readily available data for industries predominantly interstate in character.

The estimated figures for September, 1938 are:

I. The number of employees covered by the Act. . . . . . . . . . . . . II,000,000

2. The number receiving less than 25 cents per hour............. 300,000

3. The number receiving less than 30 cents per hour............. 550,000

4. The number receiving less than 40 cents per hour............. I,4I8,000

5. The number working more than 44 hours...................

6. The number working more than 42 hours................

7. The number working more than 40 hours per week........... $2,184,000$

It should be noted that the figures for employees receiving less than 25 cents per hour and those working more than 44 hours per week are the results of extremely conservative estimates, although some workers may have been included who will be found on further interpretation or court review to be exempt from the Act. An example of possible overstatement is the fact that no attempt has been made to estimate the number of coal operatives who may be engaged in enterprises producing coal that is consumed within the state. Also, while a substantial deduction was made from the total of quarrying workers to allow for local sales, the deduction may prove to have been too small. Then, too, it is quite likely that many enterprises with fewer than 6 workers will be found to be engaged in the production of goods for interstate commerce; in the present estimates, 220,000 employees of small manufacturing firms were deleted to allow for the possibility that firms of this size are engaged in local business exclusively. The employment figures included for wholesaling were also very conservative; only about 300,000 out of a total of approximately $1,400,000$ were included in the coverage estimate. No employees engaged in construction and maintenance of highways were included, although the opinion of counsel for the Division is that employees on interstate highway construction are covered by the Act. No estimate was made of the number of employees of mail-order companies who are engaged in interstate commerce, or of main office and warehouse employees of chain stores. All retailing employees were omitted.

It may appear to some that the resulting estimate of about II,000,000 employees covered by the Fair Labor Standards Act is rather low, in view of the fact that the Census of Occupations of I930 shows a total of over $48,000,000$ gainful workers. It should be remembered, however, that the Act does not cover farm labor, retail trade, domestic and personal service, governmental service, or the self-employed. These exclusions from Act coverage are also responsible for the small number estimated to be receiving less than 25 cents an hour as of September, 1938 , since employment in agriculture, retail trade, and domestic service includes a very large proportion of the low-paid workers in the United States.

The following table shows the distribution of $10,670,000$ covered employees by major industry groups: 
Table I. Number of Employees Covered by the Fatr Labor Standards Act, by Major INDUSTRY Groups, SEPTEMBER, I938

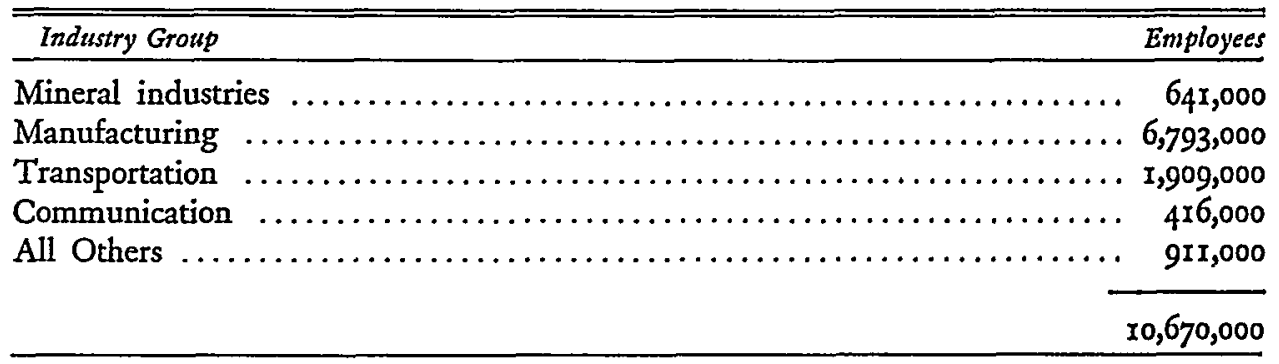

The above figures do not include nearly 200,000 homeworkers who are covered by the Act, and also exclude about ro,00o covered employees in Alaska and Hawaii. The total coverage in September, I938 was approximately $10,864,000$, geographically distributed as follows:

Table 2. Number of Employees ${ }^{1}$ Covered by the Fair Labor Standards Act, by Staths, SEPTEMBER, I938

\begin{tabular}{|c|c|c|c|}
\hline States & Employees & States & Employees \\
\hline Maine & & South Carolina...$\ldots \ldots \ldots$. & 139,625 \\
\hline New Ham & $68,97^{8}$ & Georgia $\ldots \ldots \ldots \ldots \ldots \ldots$ & 174,379 \\
\hline Vermont & 25,451 & Florida .. & 66,524 \\
\hline Massachusetts & 539,688 & Kentucky ............... & 138,972 \\
\hline Rhode Island & $I 2 I, 571$ & Tennessee $\ldots \ldots \ldots \ldots \ldots$ & 162,872 \\
\hline Connecticut . & 284,922 & Alabama $\ldots \ldots \ldots \ldots \ldots \ldots$ & 135,697 \\
\hline New York & $1,084,385$ & Mississippi $\ldots \ldots \ldots \ldots \ldots \ldots$ & $3^{8,736}$ \\
\hline ersey & $55^{8,495}$ & Arkansas $\ldots \ldots \ldots \ldots \ldots \ldots$ & $6 r, 61 x$ \\
\hline Pennsyl & $x, 177,286$ & Louisiana.$\ldots \ldots \ldots \ldots \ldots$ & 92,625 \\
\hline Ohio .. & 792,717 & klahoma $\ldots \ldots \ldots \ldots \ldots \ldots$ & 86,480 \\
\hline Indiana & $390,46 \mathrm{~T}$ & Texas $\ldots \ldots \ldots \ldots \ldots \ldots \ldots$ & 231,707 \\
\hline Illinois . & 841 & Iontana ... & 32,606 \\
\hline Michigan & 584,183 & Idaho .... & 19,709 \\
\hline Wisconsin & 310,418 & Wyoming . . & 14,595 \\
\hline Minnesota. & $I_{49}, 886$ & ado .... & $6 \pi, 674$ \\
\hline$\ldots \ldots \ldots \ldots \ldots$ & x23,679 & New Mexico ............. & $x 6,454$ \\
\hline ssouri .. & 251,328 & Arizona $\ldots \ldots \ldots \ldots \ldots \ldots$ & $29,5^{86}$ \\
\hline North Dakota & $x 2,233$ & Utah .... & 34,856 \\
\hline th Dakota .. & 12,217 & evada $\ldots .$. & $8,5^{89}$ \\
\hline Nebraska .... & 60,971 & lington . & 136,137 \\
\hline Kansas . & x10,793 & n $\ldots \ldots \ldots \ldots \ldots$ & 86,687 \\
\hline Delaware & 22,778 & California $\ldots \ldots \ldots \ldots \ldots \ldots$ & 482,152 \\
\hline Maryland $\ldots \ldots$ & Igr,066 & Alaska $^{2} \ldots \ldots \ldots \ldots \ldots \ldots \ldots$ & 2,953 \\
\hline trict of Columbia... & 26,342 & Hawaïi $^{3} \ldots$ & . 7,991 \\
\hline Virginia $\ldots \ldots \ldots \ldots$ & 192,582 & Puerto Rico ${ }^{4}$ & 101,702 \\
\hline West Virginia . & 183,074 & & \\
\hline North Carolina...$\ldots \ldots \ldots$ & 293,258 & Total ............... & 864,214 \\
\hline
\end{tabular}

${ }^{2}$ Includes about r35,000 homeworkers (exclusive of Territories).

2 As of 1935 .

${ }^{3}$ As of $1929-30$.

As of $1937-38$. Includes 60,000 homeworkers. 
The tentative total of nearly II million covered employees is roughly one-third of the total number of wage earners and salaried employees in the United States. The problem of estimating the number of covered employees affected directly by the wage and hour provisions embodied in the Act was even more difficult. The Fair Labor Standards Act established a minimum hourly wage of 25 cents and time-and-a-half pay for hours worked in excess of 44 hours per week, effective October 24, 1938. Employees working at less than the stated minimum wage or working more than 44 hours and not receiving the prescribed penalty wage for overtime were, therefore, immediately affected by the provisions of the Act. The number of employees receiving less than 25 cents per hour in September, I938, is estimated at more than 174,000 for the 48 states, and more than 216,000 for the United States and Puerto Rico. Some obvious sources of shortage, for which no accurate correction could be made on the basis of available data, are the following:

(r) The above estimate does not include home workers. There were about 135,000 home workers in continental United States and about 60,000 in Puerto Rico in September, I938. Although the amount of home work done in the country as a whole may be highly variable, there is no doubt that a large number of persons were actually so employed in that month. Studies by the Women's Bureau and other agencies show that wages received for such work are generally very low, and a very large proportion of those doing home work just before the effective date of the 25 cent minimum wage were unquestionably earning less than that wage. The actual number of low-wage employees probably far exceeded 25,000 , even if a large deduction is made for sporadic work in order to put the estimate in terms of substantial employment during the month. (It may be noted, incidentally, that many of the additional home workers per household are children, whose employment is subject to control of the Children's Bureau under Section 12 of the Fair Labor Standards Act.)

(2) It was not possible to estimate accurately the number of low-wage employees in some industries in which the wages tend to be clustered around several concentration points instead of being grouped closely around the general average. For example, the estimate may understate by as many as 20,000 or 30,000 the number of employees receiving less than 25 cents as common laborers in one or two industries alone, and by 40,000 or more for the entire coverage of the Act. The unfavorable conditions of business for several months preceding September increase the likelihood that the understatement was substantial.

(3) The estimates were developed largely from special surveys made by the Division of Wage and Hour Statistics of the Bureau of Labor Statistics and from figures reported regularly to that Bureau. With reference to the latter, particularly, it must be noted that voluntary reporting to governmental agencies commonly introduces some bias in the data because the reporting establishments tend to be those maintaining high standards in trade practices and labor relations. Statistical analysis based on such reported figures tends to understate the proportion of employees receiving very low wages. 
(4) Another statistical difficulty tending to reduce the estimate of the number of employees receiving less than 25 cents is the fact that the few low-wage employees in industries with high average wages are so small a proportion of the total in their respective industries that they may not be shown precisely in frequency distributions of wages. It was not possible with the data available to estimate accurately the number of employees receiving less than 25 cents per hour for any industry with an average wage of 65 cents or more. More than five million employees covered by the Act were attached to industries in this class. The estimate given above-216,000does not include any employees in these industries. Nevertheless, it is quite likely that these industries employed 30,000 or more workers as general helpers, errand boys, handymen and in other low-wage occupations, since there are nearly 20,000 establishments in these industries.

(5) Accurate surveys may reveal considerable numbers of workers falling within the scope of the Act in enterprises omitted from the present estimates because the nature of the business done or the small number of wage earners per establishment introduced some uncertainty as to whether these enterprises should be included.

If a rough estimate of the number of employees coming under each of the groups mentioned in the above comments is included, the total would have to be raised by more than roo,000, making a roughly estimated total of more than 300,000 (see fig. $\mathrm{r}$ ) receiving less than 25 cents per hour.

Figure x. Number of Employees Covered by the Fair Labor Standards Act, Receiving Less Than 25, 30, and 40 Cents Per Hour in September, 1938
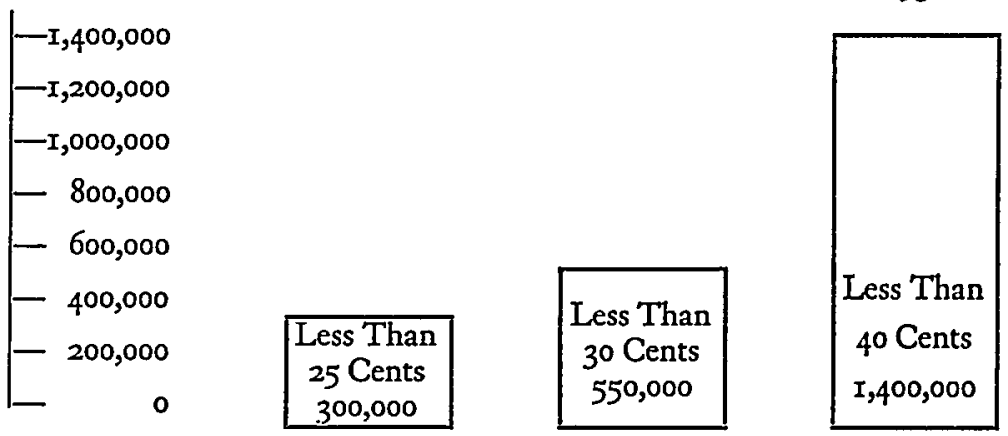

Because of the many difficulties involved in an estimate of the number of low paid workers covered by the Act, no attempt is made herein to present these figures for geographic areas or industry groups. Extensive and detailed additional study of the wage structure in individual industries and in specific areas is necessary before such estimates can be made with reasonable assurance of accuracy. The total given above must be regarded as a preliminary statement of the minimum number of employees whose wages were below 25 cents in the month preceding the effective date of the 25 cent minimum and who were, therefore, affected immediately by the wage provisions of the Act. It was not possible in the present account to extend the estimate reached for the United States as a whole-2I6,000-with equal soundness to the types 
of enterprises referred to in the remarks listed above or to subdivide that estimate by region and by industry.

A general minimum wage of 40 cents per hour for employees covered becomes effective after seven years of operation of the Fair Labor Standards Act. A number of persons now receiving less than 40 cents may be affected in the near future by wage orders gradually increasing the minimum wage in the industries to which they are attached. The following table (see also Fig. 2) shows the estimated number of employees receiving less than 40 cents in September, 1938, by industry groups.

Table 3. Number of Employees Covered by the Fair Labor Standards Act, ${ }^{5}$ Average Hourdy Earnings, and Number Receiving Less Than 40 Cents Per Hour, by INDUSTRY GROUP, SEPTEMBER, I938

\begin{tabular}{cccc}
\hline \hline & Total Number & & Number of \\
Industry Group & of & Average & Employees \\
& Employees & Hourly & Receiving Less \\
& covered & Earnings & Than 4o Cents \\
& (thousands) & (cents) $\mathbf{6}$ & (thousands) \\
\hline
\end{tabular}

Manufacturing

Iron and Steel and their Products, not including machinery ............. $\quad 652$

Machinery ............................... 657

Transportation Equipment $\ldots \ldots \ldots \ldots \ldots . \quad 35^{\mathrm{I}}$

Nonferrous Metal Products ............. $\quad 169$

Lumber and Allied Products............ $44^{\circ}$

Stone, Clay and Glass ............... $\quad$ I50

Textiles and their Products:

Fabrics .................... gor

Wearing Apparel $\ldots \ldots \ldots \ldots \ldots \ldots \ldots$ 55

Leather ...................... 242

Food and Kindred Products ........... 678

Tobacco .....................

Paper and Printing ............... 406

Chemicals and Allied Products .......... 280

Rubber ...................... I02

Not Otherwise Classified:

Durable ..................... 595

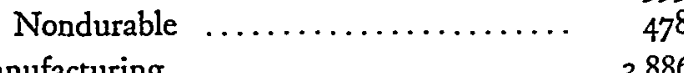

Non-Manufacturing $\ldots \ldots \ldots \ldots \ldots \ldots \ldots \ldots . \quad 3,886$

Total, Excluding Puerto Rico............ I0,629

$75 \cdot 3$

72.1

89.7

68.I

52.6

63.2

29

28

I

15

III

I6

$\begin{array}{rrr}I & 46.2 & 373 \\ \text { I } & 53.9 & 146 \\ 2 & 52.4 & 64 \\ 8 & 57.6 & 163 \\ \text { I } & 45.8 & 36 \\ 6 & 76.5 & 31 \\ 0 & 74.4 & 28 \\ 2 & 75.8 & 8\end{array}$

Total, Including Puerto Rico............. Io,670

$\begin{array}{lr}70.8 & 27 \\ 57.7 & 84 \\ 68 . \mathrm{I}^{5} & 2 \mathrm{I} 6 \\ & \mathrm{I}, 376 \\ & \mathrm{I}, 4 \mathrm{I} 8\end{array}$

These estimates are on somewhat firmer ground than the corresponding figures for employees receiving less than 25 cents. Understatements or errors characterizing the latter are, of course, involved in the attempt to count the number getting less than 40 cents, but their proportionate influence is greatly reduced in the larger totals.

Estimates by Economic Section, Wage and Hour Division.

- Data from Employment and Payrolls, September, 1938, Bureau of Labor Statistics, pp. I0-13. 
Figure 2. Employees Covered by Industry Committees and Distribution of All Other Employees Covered by the Fair Labor Standards Act by Industry Percentage Receiving Less Than 40 Cents Per Hour in September, i938

- r $~ M i l l i o n$
-10 Million
-9 Million
-8 Million
-7 Million
-6 Million
-5 Million
-4 Million
-3 Million
-2 Million
-1 Million
-0

Industries* in Which

Less Than $10 \%$

Received Less

Than 40 Cents. $3,768,000$

Industries* in Which

I0-25\% Received

Less Than

40 Cents. $\cdot 3,805,000$

Industries* in Which

$25 \%$ or More Received

Less Than 40 Cents ................

Apparel†.......................543,000

Textilest.......................582,000

* Excluding Employees Covered by the Textile and Apparel Industry Committees.

+Under Apparel Committee, as of November 1938, 512,000; under Textile Committee, as of November, $1938,600,000$. The figures for these two Industries differ from those shown in the Tables in this Section; the figures in this chart are based on definitions of Industry Committee coverage.

In March, r939, the total of covered employees stood at about eleven and one-quarter million. By May, 1939, nearly one and three-quarters million employees were included in industries for which committees had already been appointed-textiles, wool, apparel, hosiery, hats, millinery and shoes.

In September, 1938, there were 1,380,000 employees working more than 44 hours per week. A still larger number of employees-1,750,000-worked more than 42 hours during the month of September. The difference between the two estimatesthose working over 44 hours and those working over 42 hours-suggests the additional number that are likely to be affected by the basic maximum for the second year of operation of the Act. Similarly, a substantially larger number of employees appear to be subject to a change in working conditions resulting from the Act at the end of two years, when the 40-hour maximum takes effect. The possibility of gradual adjustment of working shift during the two years before the effective date of the 40-hour maximum is likely to result in reducing the number of overtime hours worked when the overtime rate becomes effective. However, there will undoubtedly be situations in which an adjustment of shift will be impractical and in those instances the men already on the job may benefit accordingly. The following table shows the number of employees who worked more than 44,42 , and 40 hours per week in September, 1938, by major industry groups. 
Table 4. Average Number of Hours Worked Per Weer, and Number Working More Than 40, 42 and 44 Hours by Industry Group, for Employees Covered by the Fair Labor Standards Act, September, $193^{7}$

\begin{tabular}{|c|c|c|c|c|}
\hline \multirow[t]{2}{*}{ Industry Group } & \multirow{2}{*}{$\begin{array}{l}\text { Average } \\
\text { Number } \\
\text { of Hours } \\
\text { Worked } 8 \\
\text { Per Week }\end{array}$} & \multicolumn{3}{|c|}{$\begin{array}{l}\text { Number of Employees } \\
\text { Working More Than }\end{array}$} \\
\hline & & 40 hours & $\begin{array}{l}42 \text { hours } \\
\text { (thousand) }\end{array}$ & 44 houts \\
\hline \multicolumn{5}{|l|}{ Manufacturing: } \\
\hline Iron and Steel and their Products, not & & & & \\
\hline including machinery $\ldots \ldots \ldots \ldots$ & 33.0 & 86 & 64 & 50 \\
\hline Machinery $\ldots \ldots \ldots \ldots \ldots \ldots \ldots$ & $35 \cdot 4$ & 80 & 69 & $4^{8}$ \\
\hline Transportation Equipment ........ & 36.4 & 55 & 92 & 32 \\
\hline Nonferrous Metal Products ....... & 37.8 & $4 I$ & 29 & 23 \\
\hline Lumber and Allied Products ...... & 40.3 & I88 & 135 & $\mathrm{Ir}_{4}$ \\
\hline $\begin{array}{l}\text { Stone, Clay and Glass ................. } \\
\text { Textiles and their Products: }\end{array}$ & 36.2 & $2 \mathbf{I}$ & I9 & 13 \\
\hline Fabrics $\ldots \ldots \ldots \ldots$ & $3^{6.3}$ & I35 & I07 & 80 \\
\hline Wearing Apparel $\ldots \ldots \ldots \ldots \ldots$ & 33.9 & 66 & 54 & 39 \\
\hline Leather $\ldots \ldots \ldots \ldots \ldots \ldots \ldots \ldots \ldots$ & $3^{6.8}$ & 39 & $3 \mathrm{I}$ & 23 \\
\hline Food and Kindred Products ............ & $4 I \cdot 3$ & $34^{\circ}$ & $27^{6}$ & $24 \mathrm{I}$ \\
\hline Tobacco $\ldots \ldots \ldots \ldots \ldots \ldots \ldots \ldots$ & 37.1 & I5 & 12 & 9 \\
\hline Paper and Printing $\ldots \ldots \ldots \ldots \ldots \ldots$ & 38.0 & 99 & 75 & 59 \\
\hline Chemicals and Allied Products .... & $3^{8} \cdot 3$ & 67 & $5 \mathrm{I}$ & 40 \\
\hline $\begin{array}{l}\text { Rubber } \ldots \ldots \ldots \ldots \ldots \ldots \ldots \ldots \ldots \ldots \\
\text { Not Otherwise Classified: }\end{array}$ & $35 \cdot 9$ & r7 & 13 & Io \\
\hline Durable...$\ldots \ldots$ & 36.0 & $7^{8}$ & 65 & 46 \\
\hline Nondurable...$\ldots \ldots \ldots$ & 37.5 & 87 & 66 & 53 \\
\hline Non-Manufacturing $\ldots \ldots \ldots \ldots \ldots \ldots \ldots \ldots$ & $37 \cdot 2^{7}$ & 753 & 579 & 492 \\
\hline Total, Excluding Puerto Rico............. & & 2,167 & $\mathbf{I , 7 3 7}$ & $\mathrm{r}, 372$ \\
\hline Total, Including Puerto Rico............. & & 2,184 & $\mathrm{I}, 75 \mathrm{I}$ & $I, 384$ \\
\hline
\end{tabular}

It is to be expected that, as knowledge concerning the Fair Labor Standards Act is disseminated among employers and employees throughout the country, there will be many requests for clarification of questions of jurisdiction. The estimates presented in the foregoing paragraphs will, of course, be affected by changes in the coverage resulting from the consideration of individual problems so arising. Substantial changes in coverage would also result from the enactment of amendments now being considered in Congress, affecting agricultural processing industries and salaried employees. Even more important perhaps is the fact that September, I938 represented a substantial drop from the level of industrial activity one year earlier, so that the number of employees falling within each of the categories estimated, particularly with respect to overtime worked, was smaller than would have been the case if the rate of industrial operation had not declined.

'Estimates by Economic Section, Wage and Hour Division.

${ }^{8}$ Data from Employment and Payrolls, September, 1938, Bureau of Labor Statistics. 
Estimated total employment of employees covered by the Act showed a substantial increase from September 1938 to March I939, rising from I0,864,000 to about II,285,ooo. It is important to note that a recovery in the level of business activity and employment would ordinarily be accompanied by a much more pronounced increase in the number of employees working overtime. This may be illustrated by the comparison of employment and overtime for September, $x 938$, and for the March-June, 1937 period of relatively high employment. In March-June, 1937, the total employ-

Figure 3. Employment of Employees Included in the Coverage of the Fair Lador Standarps Act, in September, r938 and the March-June Peax, 1937

Million Employees
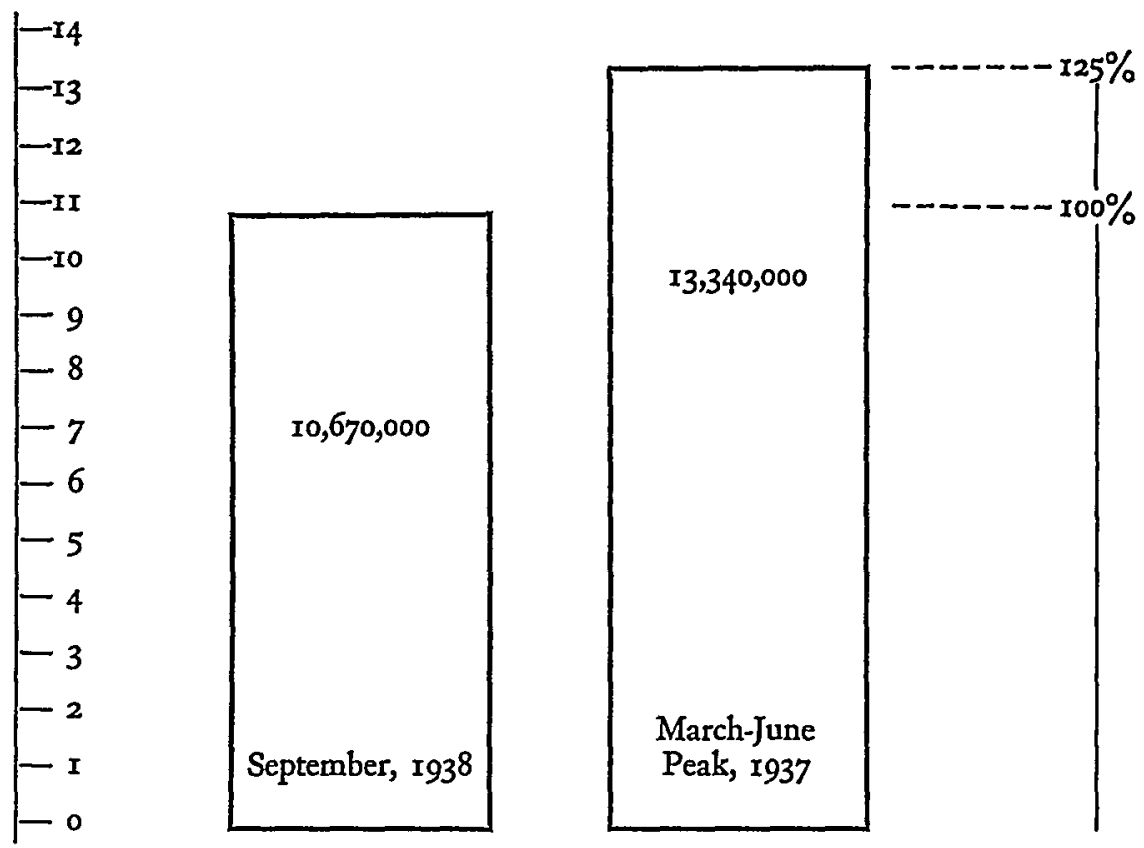

Number of Employees Included in the Coverage of the Fatr Labor Standards Act, Working More than 42 Hours Per WeEk IN September, I938 and March-June Peak, I937

Million Employees

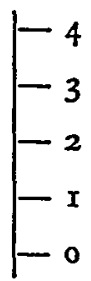

$1,751,000$ September, 1938

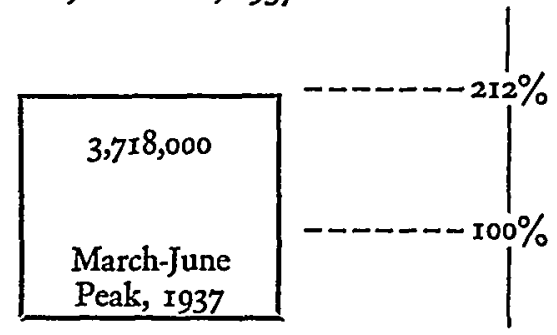


ment of employees subsequently covered by the Fair Labor Standards Act was 25 per cent more than the corresponding figure for September, 1938; however, the number of employees working more than 42 hours per week in March-June, I937 was rr2 per cent above the number in September, r938. (See Fig. 3.) With a comparable future recovery in business activity, the sharply increased overtime hours worked become potential jobs under the Act, unless the overtime work is due to a seasonal peak that can not be smoothed.

In a number of instances there have been reports that workers who had been receiving less than 25 cents had been laid off and replaced by more efficient workers. There is no evidence to show that such replacements have resulted in a marked reduction of the number of wage earners covered by the Act. To the extent that the new workers are actually much more efficient than those laid off, some curtailment of the total number of man-hours worked might occur. It is also possible that in some instances the difference in labor costs involved in raising the pre-Act wage rate to the 25-cent minimum may be sufficient to stimulate mechanization of tasks suitable for machine operation but hitherto done by hand because of low wage rates. Such technological displacement of labor is less likely if there is an actual difference in the efficiency of workers procurable at 25 cents as compared with workers hitherto employed at less than 25 cents per hour. The long-time technological effects of the minimum wage may be expected to include some shifts from hand-labor on simple tasks to better-paid machine-tending jobs and some increased investment in machine installations.

In connection with the Act's employee coverage, it may be noted that another point which has been mentioned in public discussion is the increasing of wages of workers receiving 25 cents or above, when those receiving lower pay in the same establishments prior to the effective date of the Act are raised to the new minimum. Under highly stable industrial conditions there undoubtedly would be considerable pressure for maintenance of differentials existing prior to the establishment of the minimum. It would be difficult to say at the present time, without further study, which industries would be affected in this respect by a minimum wage as low as 25 cents. This consideration may become one of marked importance during the sevenyear period within which it is expected that the minimum wage per hour will be raised toward 40 cents. However, it is still much too early to attempt a factual appraisal of the net coverage effects of the Act's minimum wage rates and overtime rates. 